\title{
AN 854-YEAR TREE-RING CHRONOLOGY OF SCOTS PINE FOR SOUTH-WEST FINLAND
}

\author{
Samuli Helama $^{1}$, Jari Holopainen ${ }^{2}$, Mauri Timonen ${ }^{3}$, Kari Mielikäinen ${ }^{4}$ \\ ${ }^{1}$ Finnish Forest Research Institute, Northern Unit, P.O. Box 16, 96301 Rovaniemi, Finland, \\ e-mail:samuli.helama@metla.fi \\ 2 Department of Geosciences and Geography, P.O. Box 64, 00041 University of Helsinki, Finland, \\ e-mail: jari.a.holopainen@helsinki.fi \\ ${ }^{3}$ Finnish Forest Research Institute, Northern Unit, P.O. Box 16, 96301 Rovaniemi, Finland, \\ e-mail:mauri.timonen@metla.fi \\ ${ }^{4}$ Finnish Forest Research Institute, Southern Unit, Vantaa, P.O. Box 18, 01301 Finland, \\ e-mail: kari.mielikainen@metla.fi
}

\begin{abstract}
A near-millennial tree-ring chronology (AD 1147-2000) is presented for south-west Finland and analyzed using dendroclimatic methods. This is a composite chronology comprising samples both from standing pine trees (Pinus sylvestris L.) and subfossil trunks as recovered from the lake sediments, with a total sample size of 189 tree-ring sample series. The series were dendrochronologically cross-dated to exact calendar years to portray variability in tree-ring widths on inter-annual and longer scales. Although the studied chronology correlates statistically significantly with other long tree-ring width chronologies from Finland over their common period (AD 1520-1993), the south-west chronology did not exhibit similarly strong mid-summer temperature or spring/early-summer precipitation signals in comparison to published chronologies. On the other hand, the south-west chronology showed highest correlations to the North Atlantic Oscillation indices in winter/spring months, this association following a dendroclimatic feature common to pine chronologies over the region and adjacent areas. Paleoclimatic comparison showed that tree-rings had varied similarly to central European spring temperatures. It is postulated that the collected and dated tree-ring material could be studied for wood surface reflectance (blue channel light intensity) and stable isotopes, which both have recently shown to correlate notably well with summer temperatures.
\end{abstract}

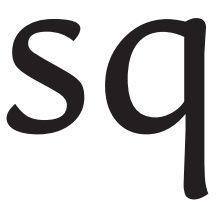

Key words: dendrochronology, North Atlantic Oscillation, paleoclimate, Pinus sylvestris, subfossil wood.

Manuscript received 29 October 2013, accepted 20 May 2014

\section{INTRODUCTION}

Tree rings provide late Quaternary paleoenvironmental records (Bradley, 1999; Walker, 2005). Millennia-long treering chronologies have recently been constructed in Fennoscandia where their development is an ongoing activity (Linderholm et al., 2010). These records consist of composite chronologies where the living-tree series are combined with tree-ring series from subfossil trunks of pine, usually preserved in subaerial conditions or sedimentary archives of small lakes or bogs (Bartholin and Karlén, 1983; Eronen et al., 1999, 2002; Grudd et al., 2000, 2002; Linderholm and Gunnarson, 2005). Majority of these chronologies originate from regions near the timberline. Construction of long chronologies is however possible also for more southern regions, either similarly using naturally preserved wood or by utilizing samples from historical buildings (Bartholin, 1987; Läänelaid and Eckstein, 2003; Koprowski et al., 2012). The value of these records for paleoenvironmental studies has been proven as the tree-ring chronologies have provided in- formation of past climate variability from inter-annual to millennial scales and for various spatial domains (Grudd et al., 2002; Helama et al., 2002, 2009a, 2009b, 2009c, 2010; Helama and Lindholm, 2003; Linderholm and Gunnarson, 2005; Gouirand et al., 2008).

Here we demonstrate the development and characteristics of a near-millennial tree-ring chronology of Scots pine for a site in south boreal forest zone in south-west Finland. This is a region where no such long tree-ring record has been available before the development of this chronology and where no subfossil wood recovered from lake sediments have previously been used for construction of tree-ring chronologies. Previously, the most recent part of the chronology has been used for dendroclimatic research and compared with instrumentally observed climate records from the same region (Holopainen et al., 2006). Similarly, the chronology was compared with large-scale climate indices (North Atlantic Oscillation NAO; Hurrell, 1995; Hurrell et al., 2001). These studies found out the sensitivity of the chronology to conditions in winter (Helama and Timonen, 2004) and spring 


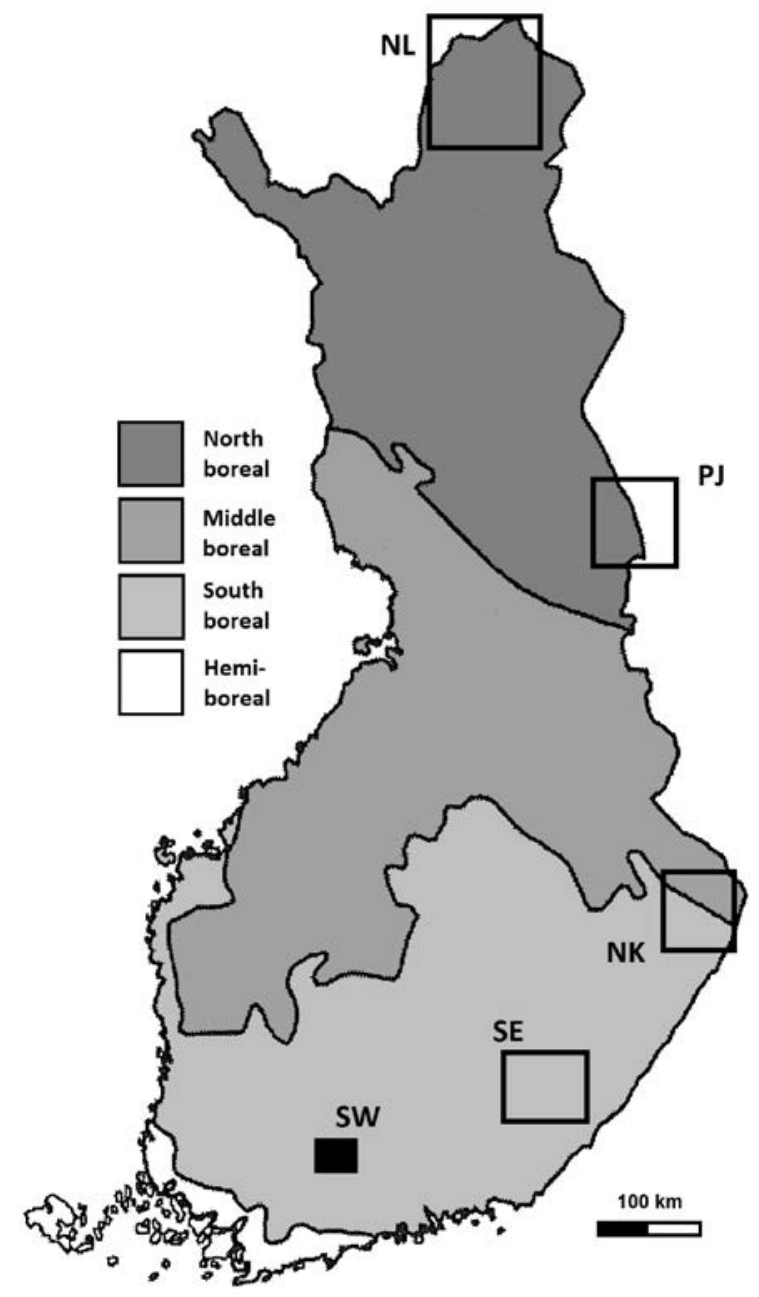

Fig. 1. Location of the study site in south-west Finland (SW) and regions from which the other long chronologies originate in northern Lapland (NL), Pääjärvi (PJ), North Karelia (NK) and south-east Finland (SE).

(Holopainen et al., 2006) climate. However, the correlation to spring temperature variability appeared temporally unstable (Holopainen et al., 2006). Moreover, the chronology was correlated with several other tree-ring chronologies of Scots pine from adjacent areas to reveal that their spatial correlativity likely reflects the past fluctuations in the NAO (Läänelaid et al., 2012).

Our objective here is to detail the chronology construction by demonstrating its temporal characteristics in sample size and chronology confidence, in addition to the tree-ring width variations. Moreover, the dendroclimatic correlations are derived using local climate data and the NAO indices. This procedure follows our previous analyses of late Holocene tree-ring chronologies from Finland (Helama et al., 2005) thus enabling comparisons of these chronologies and characterizing the properties of the south-west Finnish chronology as paleoenvironmental record. Additional comparison is made for the subfossil part of the chronology by comparing the tree-ring variations in the study region with the temperature variability as reconstructed for central Europe using documentary data (Pfister and Brádzil, 1999) over the 16 th century.

\section{MATERIAL AND METHODS}

Our tree-ring material originates from Lake Kaitajärvi and Lake Vähä-Melkutinjärvi $\left(60^{\circ} 40^{\prime} \mathrm{N}, 23^{\circ} 35^{\prime} \mathrm{E}\right)$ situated in south-west Finland (Fig. 1). The site is located in the south boreal zone (Ahti et al., 1968). This tree-ring dataset of Scots pine (Pinus sylvestris L.) comprise 189 series. Living tree samples were cored at the $\mathrm{m}$ trees growing at the shore using increment borer at breast height. Subfossil samples were recovered from lake sediments. Disks were cut by saw after lifting the trunks to the surface and sampled trunks were returned into the lake. Series of tree-ring widths were produced by measuring the ring-widths under a light-microscope to the nearest $0.01 \mathrm{~mm}$. The sample series were dated using treering cross-dating, a routine of dendrochronology, where the temporal variability of conspicuously wide and narrow rings are examined and each ring can be dated to exact calendar years (Fritts, 1976). Cross-dating was obtained using numerical procedures (Hol- mes, 1983; Van Deusen, 1990), in addition to visual comparison of the plotted measurement series on the computer screen. The dating process initiates from the cross-dating of series from living trees. The subfossil series are cross-dated against each other and the subfossil chronology is cross- dated against the obtained chronology of living trees. The final chronology comprises 47 sample series from living pines and 142 subfossil series. Mean length of the series was 143 years. The chronology covered the period AD 1147-2000.

Following previous tree-ring studies in adjacent areas (Helama et al., 2005, 2013), the double-detrending of the tree-ring series was carried out. To do so, individual tree-ring series were transformed into indexed series in the process called tree-ring standardization (Fritts, 1976; Cook, 1985; Helama et al., 2004). This was done to remove the age-size related trend in radial growth using the modified negative exponential curve, linear regression line or line through the series mean (Fritts et al., 1969). Indices were derived from the modeled curve by division. Second, a spline function (Cook and Peters, 1981) was fitted to the series of these indices and a new series of tree-ring indices were extracted from this curve as ratios. The rigidity of the spline was determined to be two-thirds of the length of each individual time series (50 $\%$ frequency response cut-off). Third, the second set of indices was pre-whitened using Box and Jenkins (1970) methods of autoregressive and moving average time series modeling (Cook, 1985). The rationale using this three-step process lies as follows. The first detrending is expected to remove the long-term growth trend from the tree-ring measurement series and to stabilize their variance. The second detrending is expected to remove growth variation related to disturbance caused by forest dynamics with additional variance stabilization (Fritts, 1976; Cook et al., 1990a; Helama et al., 2004). Pre-whitening transforms autocorrelated series into serially independent observations (Cook, 1985; Monserud, 1986). Expressed population signal (EPS) was used as indication of chronology reliability. The EPS provides an expression of common variability among the available tree-ring series through time. The pre-determined limit of EPS $>0.85$ can be used as a reasonable albeit objective value for an acceptable level of chronology confidence (Wigley et al., 1984). 


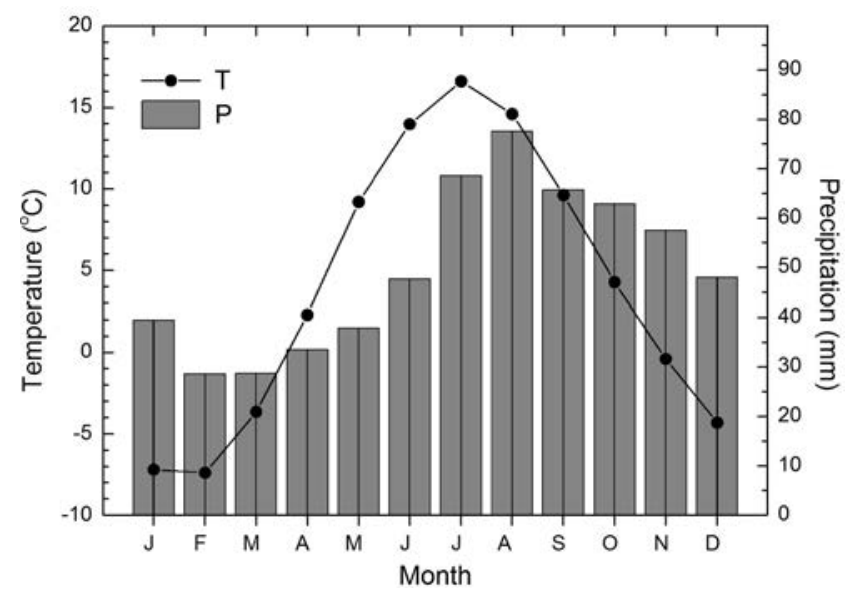

Fig. 2. Ombrothermic diagram of long-term mean monthly temperatures $(\mathrm{T})$ and monthly precipitation sums $(\mathrm{P})$ in the locality over the dendroclimatic study period (1910-1993).

Tree-ring chronologies were produced by averaging the annual values of indices using a bi-weight robust mean (Cook, 1985; Cook et al., 1990b). In order to adjust the chronology variance for sample size, each annual value was scaled by an effective number of independent samples available in each year as demonstrated by Osborn et al. (1997). The long-term and period variations in the chronology were illustrated by applying a smoothing spline function (Cook and Peters, 1981) to the annual chronology values. Hereafter, the prewhitened indices were used in the analyses, if not otherwise mentioned.

Local climatic data was adopted as mean monthly temperatures and precipitation sums as estimated (Fig. 2) from the climate records made by the Finnish Meteorological Institute (Ojansuu and Henttonen, 1983). Moreover, the monthly indices of the North Atlantic Oscillation (NAO; Hurrell, 1995) were used for comparisons. The variations described by the NAO indices are characterized by the oscillation of atmospheric masses producing large-scale changes in the mean wind speed and direction over the North Atlantic, where the positive (negative) NAO phases commonly occur with strengthened (attenuated) westerlies and thus milder and moister (cooler and drier) winters and springtime conditions on local scale (Uvo and Berndtsson, 2002; Helama and Holopainen, 2012). Pearson correlation coefficients were computed between these climatic records and the tree-ring chronology. Correlations were calculated over the period 1909-1993. The particular period was common to our previous analyses (Helama et al., 2005) thus making the dendroclimatic coefficients between that and this study comparable with each other.

\section{RESULTS}

\section{Tree-ring properties}

On average, the modern and subfossil pine series contained 109 and 154 rings with mean radii (sum of measured ARWs) of 164 and $150 \mathrm{~mm}$, respectively, these values translating into absolute growth rates of 1.50 and $0.97 \mathrm{~mm} /$ year. These figures indicate that the cored pines had grown faster
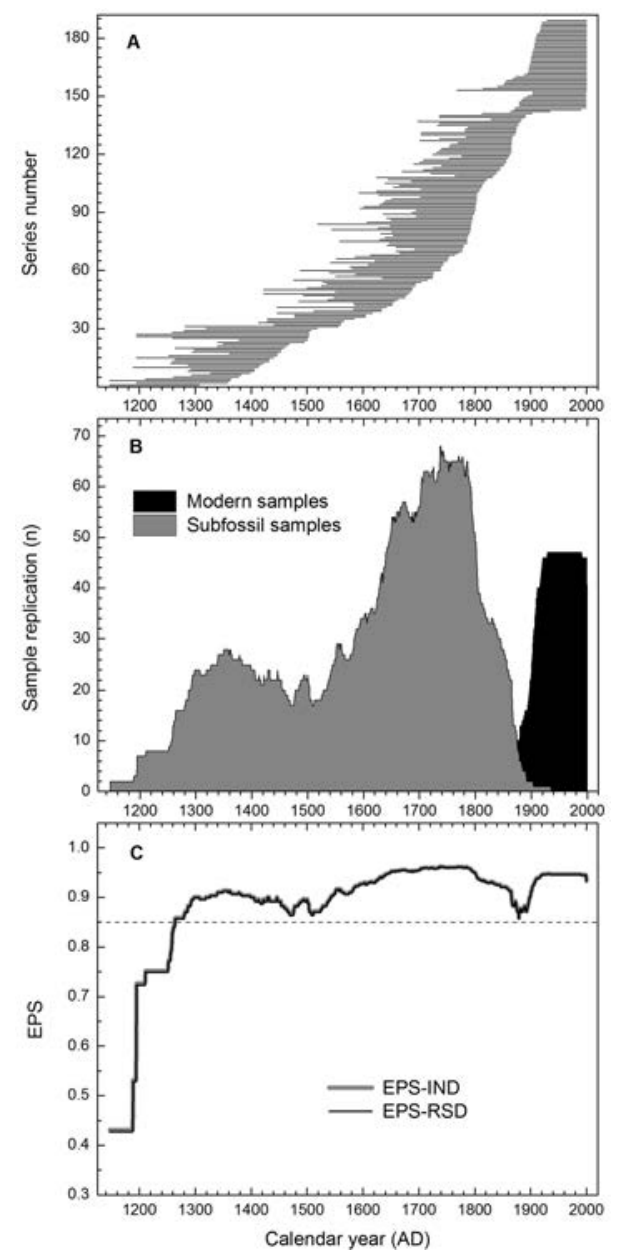

Fig. 3. Tree-ring chronology for south-west Finland. Each sample of the chronology, represented by a horizontal bar, is shown in its position corresponding to the dendrochronological cross-dating (a). Replication of the samples as a function of time (b). The expressed population signal (EPS) and its temporal variations relative to the pre-determined level of 0.85 (horizontal dashed line) (c).

than the ancient pines recovered from the lake sediment. The oldest living pine was more than 233 years old. Its first ring at breast height had grown in 1768. In comparison, the biologically oldest subfossil pine contained 309 rings.

\section{Chronology confidence}

Sample size fluctuates through time with highest number of replication during the 18th century (Fig. 3). Periods of low sample replication occur during the last half of the 19th century and before 17 th century. Correlation among tree-ring series averaged 0.275 and 0.272 , respectively, as calculated from detrended and further pre-whitened indices. Using these values and the EPS-statistic, the chronologies build using detrended and further pre-whitened indices showed the EPS-statistic over the pre-determined level of 0.85 continuously since 1264 .

\section{Tree-ring fluctuations}

Chronologies illustrated tree-ring growth variations on inter-annual to longer scales (Fig. 4). The most anomalous 

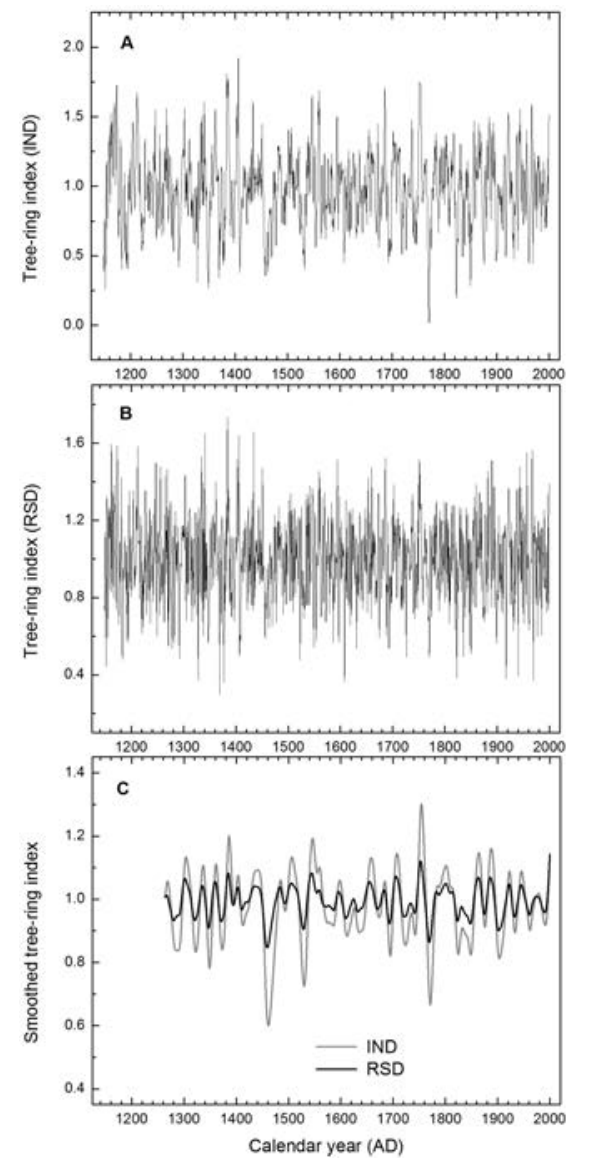

Fig. 4. Tree-ring chronologies based on detrended (a) and further pre-whitened (b) indices. Long-term variations of the chronologies are highlighted using their smoothed versions (c). The smoothed chronologies are shown since their EPS-statistic exceed the 0.85 level (Fig. 3c).

positive indices were found in 1384, 1434, 1341 and 1406. No similarly positive indices occurred in the course of the 20th century. The eye-catchingly anomalous negative growth indices were found in 1328, 1369, 1377, 1608 and 1823. During the 20th century, the years 1917, 1940 and 1969 underwent similarly negative indices. Notable periods of ameliorated growth occurred in the 1380s, 1540s and 1750s. Corresponding period of deteriorated growth were evident in the $1460 \mathrm{~s}, 1530 \mathrm{~s}, 1770 \mathrm{~s}$. This shows that the period from $1530 \mathrm{~s}$ to 1540 s experienced a marked change in the growth from low to high index values.

\section{Dendroclimatic correlations}

Tree-rings were found to correlate statistically significantly with several monthly climatic variables as follows. Positive correlations were found for temperatures in February and March (Fig. 5a). Calculating the correlation between the tree-ring chronology and the February-March temperature series showed a correlation coefficient of $0.338(\mathrm{p}<0.01)$. This indicates that the tree-ring growth was benefitted from mild winter conditions prior to the actual start of the growing season. Moreover, the tree-ring chronology correlated positively with precipitation in March and June (Fig. 5b). Since the
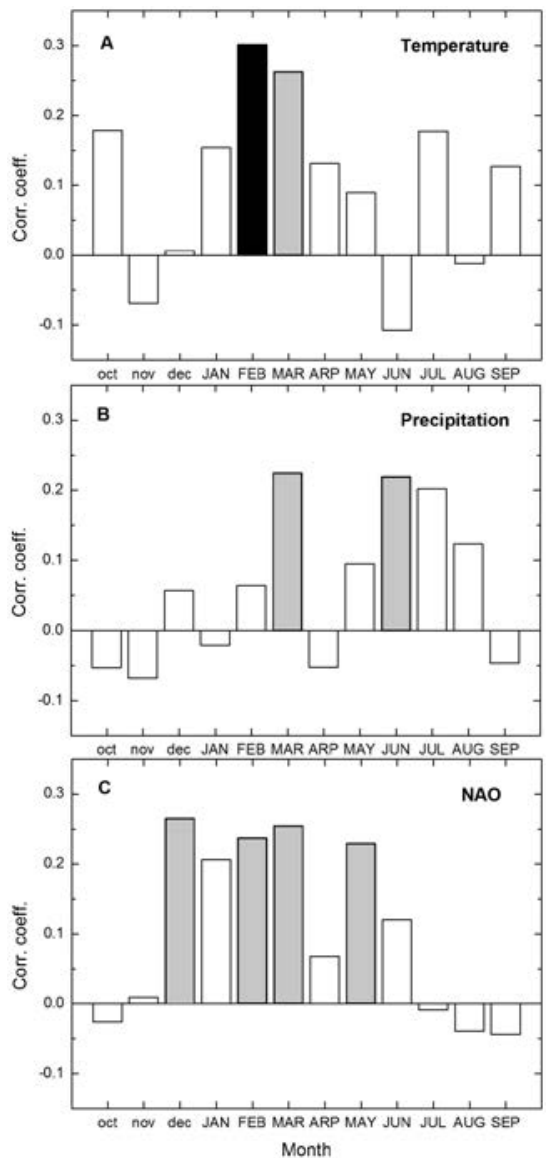

Fig. 5. Dendroclimatic correlations computed between the monthly climate variables and tree-rings (AD 1910-1993). Columns show the correlation coefficients for temperature (a) and precipitation (b) variables as well as the indices of the North Atlantic Oscillation (NAO) (c) of the previous (small letters) and concurrent year (capital letters). Statistically significant relationships are indicated as black (0.01 level) and gray (0.05 level) histograms.

local March mean temperature typically remains below zero (Fig. 2), the correlativity to March precipitation likely demonstrates the positive effects from increased snowfall on these pines.

\section{NAO-correlations}

Statistically significant correlations to the NAO indices were found for winter and spring months preceding the growing season in December, February, March and May (Fig. 5c). Highest correlation between the NAO indices and tree-rings was found for a multi-monthly season (December through May) combining the winter and spring months. This correlation showed a coefficient of $0.483(\mathrm{p}<0.01)$. This multi-monthly NAO index recognized firm linkages with the local temperature and precipitation records with statistically significant correlation coefficients of $0.628(\mathrm{p}<0.01)$ and $0.295(\mathrm{p}<0.01)$, respectively. These associations demonstrate the NAO-driven effects on the local winter (December through May) climate variability where the westerly winds, as indicated by the positive NAO index, arrive into the region with warmer and more humid air masses. 


\section{DISCUSSION}

We have demonstrated the main characteristics of the near-millennial tree-ring chronology from south-west Finland. Comparison between this chronology with other long Finnish tree-ring chronologies of Scots pine show that the tree-ring variations of the studied chronology correlate best with the chronology from south-east Finland (Fig. 6), that is, with its geographically closest record. Moreover, the correlations decrease systematically as the distance between the chronologies increases. This decline occurs in accord with the previous views on spatial tree-ring correlativity in Fennoscandia (Schweingruber, 1988; Helama et al., 2005) and likely results, in part, from decreasing similarity between the climate variability with increasing distance. Even a stronger factor behind the decline is likely to originate from dissimilarity of tree-ring growth response to climate in different ecological positions from southern boreal forests to the northern timberline. Comparison of these dendroclimatic relationships is presented below.

\section{Cold season and hydroclimate signals}

Our results confirmed the previous findings that these tree-rings correlate notably with the climatic variables in winter and spring seasons (Helama and Timonen, 2004; Holopainen et al., 2006) and that the tree-ring variability follows the positive and negative NAO phases at least over the instrumental period (Helama and Timonen, 2004; Läänelaid et al., 2012). The NAO is an atmospheric oscillation of synoptic scale over the North Atlantic sector where the westerlies bring warmer and moister air-masses onto study region (Uvo and Berndtsson, 2002; Helama and Holopainen, 2012). This condition is demonstrated by the positive NAO index. In its opposite phase, the westerlies are attenuated with predominance of cooler and drier conditions over the north-west Europe (Hurrell, 1995; Hurrell et al., 2001). In this study, the atmospheric phenomenon was indicated by markedly positive correlations between the NAO index and the local temperature and precipitation variability during the winter and spring seasons. Comparison of the NAO-correlations in south-west Finland with previously established NAO-correlations (Helama et al., 2005) shows that the winter (December) NAO index correlates with pine growth over extended areas (Fig. 7a). Similar correlativity of Scots pine tree-rings to winter NAO index has been observed over multiple sites in Finland, Estonia, Gotland, and north-west Russia (Lindholm et al., 2001). Moreover, it has been found that the prolonged periods of positive NAO phase come with increased correlation between the tree-ring chronologies over the same region through the past millennia (Helama et al., 2005; Läänelaid et al., 2012).

It is evident that the tree-ring growth is generally benefitted from the mild and moist winter/spring conditions through Finland and adjacent areas as in fact evidenced by statistically significant correlations to temperature (February through March; Fig. 5a) and precipitation (March; Fig. 5b) variables of cold season. The most obvious paleoenvironmental change as indicated by the chronology occurred as the mid-1500s event, when the anomalously low indices in the

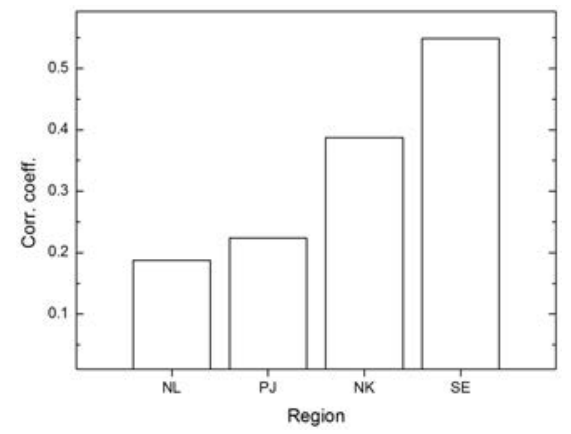

Fig. 6. Correlations between the tree-ring chronology of this study and the other long Finnish tree-ring chronologies (Helama et $a l ., 2005)$ originating from northern Lapland (NL), Pääärvi region (PJ), North Karelia (NK), and south-east Finland (SE) (see also Fig. 1). Correlations were calculated over the common period (AD 1520-1993). All correlations are statistically significant $(\mathrm{p}<0.01)$.

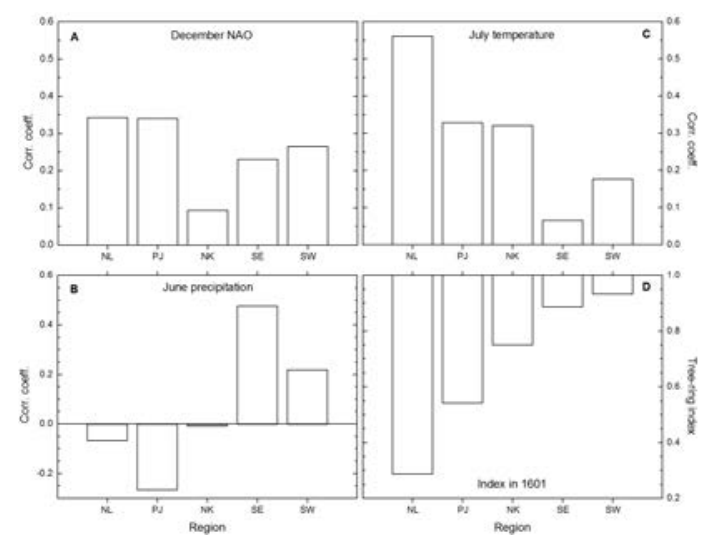

Fig. 7. Comparison of the Finnish millennial tree-ring chronologies using their dendroclimatic correlations (Helama et al., 2005) to North Atlantic Oscillation (NAO) index in December preceding the growing season (a), precipitation in June (b), temperature in July (c), and their tree-ring indices in AD 1601 (d). Chronologies originate from northern Lapland (NL), Pääjärvi region (PJ), North Karelia (NK), south-east Finland (SE) and this study (SW) (see also Fig. 1).

1530s were followed by the high index values in the 1540s. Of note, Pfister and Brádzil (1999) detailed the temperature and precipitation variation in central Europe using documentary data. They further reconstructed climate variability over the 16th century using decadal estimates of past temperature and precipitation. We compared their reconstructions to decadally averaged tree-ring indices from south-west Finland and obtained highest correlation with coefficient of $0.751(p<0.05)$ reasonably for a spring temperature association (Fig. 8). Moreover, the temperature reconstruction (Pfister and Brádzil, 1999) exhibited a positive change towards the 1540 s, comparable to indications by the studied tree-ring chronology. These findings implied a rather similar spring temperature changes in central and northern Europe, at least on decadal scale, during the 16th century. In a previous analysis, the SW Finnish tree-rings were seen to correlate positively with reconstructed and instrumentally recorded spring temperature variations in the same region since 1750s (Holopainen et al. 2006). The strength of the correlativity was however temporally unstable. Similarly, the correspon- 


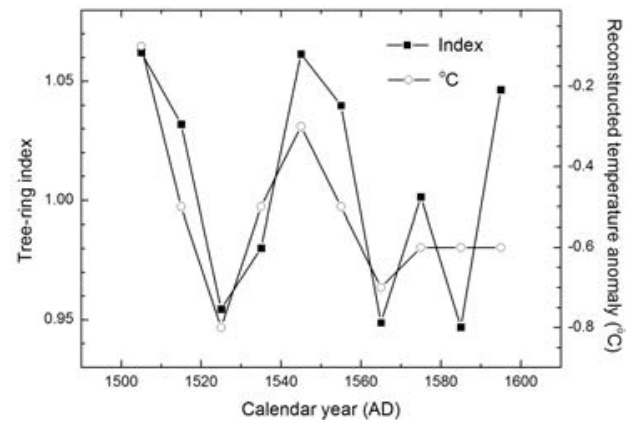

Fig. 8. Decadal comparison of the south-west Finnish tree-ring index and the estimated central European temperature variations as anomalies form the reference period 1901-1960 (Pfister and Brádzil, 1999).

dence between the two records here (Fig. 8) is somewhat muted during the last decades of the 16th century.

Previously, the millennial tree-ring chronology of Scots pine from south-east Finland was used as a proxy record for reconstructing the paleoclimatic variations in past springsummer (May through June) precipitation (Helama and Lindholm, 2003; Helama et al., 2009b). Similarly, the tree-rings correlated statistically significantly with June precipitation in south-western Finland (Fig. 5b). However, the dendroclimatic signal of summer precipitation was notably lower in south-west Finland, in comparison to the strength of this signal in tree-ring growth in south-east Finland (Fig. 7b). Interestingly, this dendroclimatic relationships was found as markedly positive only for the sites in south boreal forests, in south-west and south-east Finland, in comparison to the more northern sites in Finland where the correlation appeared negative (Fig. $7 b$ ).

\section{Summer temperature signals}

In Fennoscandia, the longest tree-ring chronologies have been commonly built for northern timberline regions where the utilization of subearial wood (Sirén, 1961; Bartholin and Karlén, 1983; Bartholin, 1987) as well as the recovery of subfossil pine trunks as preserved within lake sediments (i.e., megafossils) started several decades ago (Eronen, 1979). These chronologies have oftentimes been used as proxy records for reconstructing the paleoclimatic temperature variations through past millennia (Grudd et al., 2002; Helama et al., 2002, 2009a, 2009c, 2010; Linderholm and Gunnarson, 2005; Gouirand et al., 2008). Naturally, their paleoclimatic value depends on their strong dendroclimatic signal of summer temperatures. Also the south-west chronology relates positively with mid-summer (July) temperatures (Fig. 5a) but the strength of this correlation is dwarfed by the high association between mid-summer temperatures in the tree-ring chronologies from more northern areas (Fig. 7c). Yet another suitable way for studying this paleoclimatic signal in Finnish tree-ring chronologies is the comparison of tree-ring indices of the chronologies in AD 1601 (Helama et al., 2005; Helama et al., 2009a). This year is known as one of the most obvious signature years in the northern tree-ring chronologies (Briffa et al., 1998) following the summertime cooling over the Northern Hemisphere due to the eruption of Huaynaputina volcano (Peru) that had occurred in the previous year (de Silva and Zielinski, 1998). As a result of this cooling, the timberline tree-rings demonstrated most severe reduction in their growth, as indicated by their very low tree-ring index, in AD 1601 (Fig. 7d). A similar, albeit attenuated, growth reaction was observed in more southern chronologies, with a pattern of gradually weaker response towards the south, with the highest tree-ring index in AD 1601 in the south-west Finnish chronology (Fig. 7d). It is obvious that the studied chronology possesses a negligible summer temperature signal in its tree-rings, in comparison to chronologies from more northern areas.

Although the summer temperature signal in the southwest Finnish chronology of tree-ring widths appeared meaningless, the collected tree-ring material could provide an improved paleoclimatic temperature proxy archive for analyses of the surface reflectance of the latewood portion of each annual ring to determine the minimum blue channel light intensity (BI). Previous studies have shown that the BI provides a highly skilled surrogate for latewood density of high-latitude pine tree-rings (McCarroll et al., 2002; Campbell et al., 2007; Wilson et al., 2011). The BI was recently (Helama et al., 2013) shown to provide a useful proxy for past temperature variations also south of the timberline, as the BI chronology of living pines explaining more than 40 percent of the summer temperature variance in North Karelia (denoted as NK in Fig. 1) in eastern Finland. Alternatively, the collected tree-ring material could be used as material for dendro-isotopic analyses. Stable carbon isotopes $\left(\delta^{13} \mathrm{C}\right)$ as extracted from Scots pine tree-rings have previously shown to provide a reasonable proxy of temperatures in North Karelia where the $\delta^{13} \mathrm{C}$ chronology explained $30-40$ percent of the summer temperature variance (Hilasvuori et al., 2009). Analyzing these properties from Scots pine tree-rings in south-west Finland for $\mathrm{BI}$ and $\delta^{13} \mathrm{C}$ chronologies over the periods of instrumental climate observations (Holopainen, 2006) will detail their exact paleoclimatic value. Another interesting opportunity would use both the $\mathrm{BI}$ and $\delta^{13} \mathrm{C}$ data as multiple proxies for common temperature signal, as an increased range of indicators is likely to result in more robust paleoclimate reconstruction.

\section{CONCLUSIONS}

Tree-ring chronology from south-west Finland provides an interesting possibility to study the paleoenvironmental variations over the past eight centuries. Although the dendroclimatic correlations between this chronology and local climate variables did not indicate straightforward opportunities for tree-ring based temperature or precipitation reconstructions, the chronology showed its potential for recording the NAO signals of winter and spring seasons. Moreover, the markedly high correlation between the tree-ring chronology and reconstructed central European temperatures during the 16 th century was demonstrated. This comparison showed that the past variations in the tree-ring width were synchronous with large-scale temperature fluctuations also during the pre-instrumental period. As a future prospect, the treering dated material may be used for more elaborated proxies 
of summer temperature via production of wood property and/or dendro-isotopic chronologies.

\section{Acknowledgements}

We thank the referee comments by two anonymous reviewers. This study was also supported by the Academy of Finland (\#251441) and the foundation of Koneen Säätiö.

\section{REFERENCES}

Ahti, T., Hämet-Ahti, L., Jalas, J., 1968. Vegetation zones and their sections in northwestern Europe. Annales Botanici Fennici 3, 169-211.

Bartholin, T. 1987. Dendrochronology in Sweden. Annales Academiae Scientiarum Fennicae 145, 79-88.

Bartholin, T.S., Karlén, W., 1983. Dendrochronology in Lapland (Dendrokronologi i Lapland). Dendrokronologiska Sällskapet $5,3-16$ (in Swedish).

Box, G.E.P., Jenkins, G.M., 1970. Time series analysis: forecasting and control. Holden-Day, San Francisco.

Bradley, R.S., 1999. Paleoclimatology: reconstructing climates of the Quaternary. Academic Press, London.

Briffa, K.R., Jones, P.D., Schweingruber, F.H., Osborn, T.J., 1998. Influence of volcanic eruptions on Northern Hemisphere over the past 600 years. Nature 393, 450-455.

Campbell, R., McCarroll, D., Loader, N.J., Grudd, H., Robertson, I., Jalkanen, R., 2007. Blue intensity in Pinus sylvestris treerings: developing a new paleoclimate proxy. The Holocene 17, 821-828.

Cook, E.R., 1985. A time series analysis approach to tree-ring standardization. Doctoral dissertation, University of Arizona, Tucson.

Cook, E., Briffa, K.R., Shiyatov, S., Mazepa, V., 1990a. Tree-ring standardization and growth-trend estimation. In: Cook, E.R., Kairiukstis, L.A. (eds.) Methods of dendrochronology: applications in the environmental science, 104-123, Kluwer Academic Publishers, Dordrecht.

Cook, E.R., Peters, K., 1981. The smoothing spline: A new approach to standardizing forest interior tree-ring width series for dendroclimatic studies. Tree-Ring Bulletin 41, 45-53.

Cook, E., Shiyatov, S., Mazepa, V., 1990b. Estimation of the mean chronology. In: Cook, E.R., Kairiukstis, L.A. (eds.) Methods of dendrochronology: applications in the environmental science, 123-132, Kluwer Academic Publishers, Dordrecht.

de Silva, S.L., Zielinski, G.A., 1998. Global influence of the AD 1600 eruption of Huaynaputina, Peru. Nature 393, 455-458.

Eronen, M., 1979. The retreat of pine forest in Finnish Lapland since the Holocene climatic optimum: A general discussion with radiocarbon evidence from subfossil pines. Fennia. 157, 93-114.

Eronen, M., Hyvärinen, H., Zetterberg, P., 1999. Holocene humidity changes in northern Finnish Lapland inferred from lake sediments and submerged Scots pines dated by tree rings. The Holocene 9, 569-580.

Eronen, M., Zetterberg, P., Briffa, K.R., Lindholm, M., Meriläinen, J., Timonen. M.. 2002. The supralong Scots pine treering record for Finnish Lapland: part 1, chronology construction and initial references. The Holocene 12, 673-680.

Fritts, H.C., 1976. Tree rings and climate. Academic Press, New York.

Fritts, H.C., Mosimann, J.E., Bottorff, C.P., 1969. A revised computer program for standardizing tree-ring series. Tree Ring Bulletin 29,15-20.

Gouirand, I., Linderholm, H.W., Moberg, A., Wohlfarth, B., 2008. On the spatiotemporal characteristics of Fennoscandian tree- ring based summer temperature reconstructions. Theoretical and Applied Climatology 91, 1-25.

Grudd, H., Briffa, K.R., Gunnarson, B.E., Linderholm, H.W., 2000. Swedish tree rings provide new evidence in support of a major, widespread environmental disruption in 1628 BC. Geophysical Research Letters 27, 2957-2960.

Grudd, H., Briffa, K.R., Karlén, W., Bartholin, T.S., Jones, P.D., Kromer, B., 2002. A 7400-year tree-ring chronology in northern Swedish Lapland: natural climatic variability expressed on annual to millennial timescales. The Holocene 12, 657-665.

Helama, S., Arentoft, B.W., Collin-Haubensak, O., Hyslop, M.D., Brandstrup, C.K., Mäkelä, H.M., Tian, Q.H., Wilson, R., 2013. Dendroclimatic signals deduced from riparian versus upland forest interior pines in North Karelia, Finland. Ecological Research 28, 1019-1028.

Helama, S., Holopainen, J., 2012. Spring temperature variability relative to the North Atlantic Oscillation and sunspots - A correlation analysis with a Monte Carlo implementation. Palaeogeography, Palaeoclimatology, Palaeoecology 326-328, 128134.

Helama, S., Lindholm M., 2003. Droughts and rainfall in southeastern Finland since AD 874, inferred from Scots pine ringwidths. Boreal Environmental Research 8, 171-183.

Helama, S, Lindholm, M, Meriläinen, J, Timonen, M, Eronen, M., 2005. Multicentennial ring-width chronologies of Scots pine along north-south gradient across Finland. Tree Ring Research $61,21-32$.

Helama, S, Lindholm, M, Timonen, M, Eronen, M., 2004. Detection of climate signal in dendrochronological data analysis: a comparison of tree-ring standardization methods. Theoretical and Applied Climatology 79, 239-254.

Helama, S., Lindholm, M., Timonen, M., Meriläinen, J., Eronen, M., 2002. The supra-long Scots pine tree-ring record for Finnish Lapland: Part 2, interannual to centennial variability in summer temperatures for 7500 years. The Holocene 12, 681687.

Helama, S., Macias Fauria, M., Mielikäinen, K., Timonen, M., Eronen, M., 2010. Sub-Milankovitch solar forcing of past climates: mid and late Holocene perspectives. Geological Society of America Bulletin 122, 1981-1988.

Helama, S., Makarenko, N.G., Karimova, L.M., Kruglun, O.A., Timonen M., Holopainen J., Meriläinen, J., Eronen, M., 2009a. Dendroclimatic transfer functions revisited: Little Ice Age and Medieval Warm Period summer temperatures reconstructed using artificial neural networks and linear algorithms. Annales Geophysicae 27, 1097-1111.

Helama, S., Meriläinen, J., Tuomenvirta, H., 2009b. Multicentennial megadrought in northern Europe coincided with a global El NiZo-Southern Oscillation drought pattern during the Medieval Climate Anomaly. Geology 37, 175-178.

Helama, S., Timonen, M., 2004. Meteorological time-series from tree-rings (Meteorologisia aikasarjoja puiden vuosilustoista). Ilmastokatsaus 9 (12): 1, 3, 5-6 (in Finnish).

Helama, S., Timonen, M., Holopainen, J., Ogurtsov, M.G., Mielikäinen, K., Eronen, M., Lindholm, M., Meriläinen, J., 2009c. Summer temperature variations in Lapland during the Medieval Warm Period and the Little Ice Age relative to natural instability of thermohaline circulation on multidecadal and multi-centennial scales. Journal of Quaternary Science 24, $450-456$.

Hilasvuori, E., Berninger, F., Sonninen, E., Tuomenvirta, H., Jungner, H., 2009. Stability of climate signal in carbon and oxygen isotope records and ring width from Scots pine (Pinus sylvestris L.) in Finland. Journal of Quaternary Science 24, 469-480.

Holmes, R.L., 1983. Computer-assisted quality control in tree-ring 
dating and measurement. Tree-Ring Bulletin 43, 69-75.

Holopainen, J., 2006. Reconstructions of Past Climates from Documentary and Natural Sources in Finland since the 18th Century. Doctoral dissertation, Department of Geology, University of Helsinki.

Holopainen, J., Helama, S., Timonen, M., 2006. Plant phenological data and tree-rings as palaeoclimate indicators since AD 1750 in SW Finland. International Journal of Biometeorology 51, 61-72.

Hurrell, J.W., 1995. Decadal trends in the North Atlantic Oscillation: regional temperatures and precipitation. Science 269, 676-679.

Hurrell, J.W., Kushnir, Y., Visbeck, M., 2001. The North Atlantic oscillation. Science 291, 603-604.

Koprowski, M., Przybylak, R., Zielski, A., Pospieszyńska, A., 2012. Tree rings of Scots pine (Pinus sylvestris L.) as a source of information about past climate in northern Poland. International Journal of Biometeorology 56, 1-10.

Läänelaid, A., Eckstein, D., 2003. Development of a tree-ring chronology of Scots pine (Pinus sylvestris L.) for Estonia as a dating tool and climatic proxy. Baltic Forestry 9, 76-82.

Läänelaid, A., Helama, S., Kull, A., Timonen, M., Jaagus, J., 2012. Common growth signal and spatial synchrony of the chronologies of tree-rings from pines in the Baltic Sea region over the last nine centuries. Dendrochronologia 30, 147-155.

Linderholm, H.W., Björklund, J., Seftigen, K., Gunnarson, B.E., Drobyshev, I., Jeong, J.- H., Stridbeck, P., Liu, Y., 2010. Dendroclimatology in Fennoscandia - from past accomplishments to future potential. Climate of the Past 6, 93-114.

Linderholm, H.W., Gunnarson, B.E., 2005. Summer climate variability in west-central Fennoscandia during the last 3600 years. Geografiska Annaler 87A, 231-241.

Lindholm, M., Eggertsson, Ó., Lovelius, N., Raspopov, O., Shumilov, O., Läänelaid, A., 2001. Growth indices of North European Scots pine record the seasonal North Atlantic Oscillation. Boreal Environmental Research 6: 275-284.

McCarroll, D., Pettigrew, E., Luckman, A., Guibal, F., Edouard, J.L., 2002. Blue reflectance provides a surrogate for latewood density of high-latitude pine tree-rings. Arctic, Antarctic and Alpine Research 34, 450-453.

Monserud, R.A., 1986. Time-series analyses of tree-ring chronologies. Forest Science 32, 349-372.

Ojansuu, R., Henttonen, H., 1983. Estimation of local values of monthly mean temperature, effective temperature sum and precipitation sum from the measurements made by the Finnish Meteorological Office. Silva Fennica 17, 143-160.

Osborn, T.J., Briffa, K.R., Jones, P.D., 1997. Adjusting variance for sample-size in tree-ring chronologies and other regional mean timeseries. Dendrochronologia 15, 89-99

Pfister, C., Brádzil, R., 1999. Climatic Variability in SixteenthCentury Europe and its Social Dimension: a synthesis. Climatic Change 43, 5-53.

Schweingruber, F. H., 1988. Tree Rings. Basics and Applications of Dendrochronology. Kluwer Academic Publishers, Dordrecht

Sirén, G., 1961. Forest limit pine as an indicator of climatic fluctuations in northern Fennoscandia in historic times (Skogsgränstallen som indicator för klimatfluktuationerna i norra fennoskandien under historisk tid). Communicationes Instituti Forestalis Fenniae 54, 1-66 (in Swedish with English summary).

Uvo, C.B., Berndtsson, R., 2002. North Atlantic Oscillation; a climatic indicator to predict hyrdopower availability in Scandinavia. Nordic Hydrology 33, 415-424.

Van Deusen, P.C., 1990. Popular formulations for modeling tree rings from climate: a unifying approach. Journal of Environmental Quality 20, 823-827.

Walker, M.J.C., 2005. Quaternary Dating Methods. Wiley, Chichester.

Wigley, T.M.L., Briffa, K.R., Jones, P.D., 1984. On the average value of correlated time series, with applications in dendroclimatology and hydrometeorology. Journal of Climate and Applied Meteorology 23, 201-213.

Wilson, R., Loader, N., Rydval, M., Paton, H., Frith, A., Mills, C., Crone, A., Edwards, C., Larsson, L., Gunnarson, B., 2011. Reconstructing Holocene climate from tree rings - the potential for a long chronology from the Scottish Highlands. The Holocene $22,3-11$. 